\title{
Anti-Dumping Regulations and Policies: Some Insights from Algeria
}

\author{
By Soheyb Salah Kahlessenane*
}

\begin{abstract}
The purpose of this paper was to highlight some laws and policies that regulate antidumping and provide some insights from Algeria. An armchair library approach was employed; a review of primary legal material borrowed from Universiti Utara Malaysia's library, Algerian High Court Library, and second materials (magazines, books, articles, reports, and online database). An exploratory approach applied to know the legislation which is related to anti-dumping in Algerian law. The results revealed that the Algerian lawgiver made huge efforts in regulating the anti-dumping laws. Over and above, Algeria has been continued to give broad attentions to limit dumping actions and protect the companies and enterprises that are working in its territory. This paper is timely, original and could read due to that it is provides a general view and crystallises a general idea about anti-dumping law and policies in Algeria.
\end{abstract}

Keywords: Anti-Dumping; Algeria; Regulations; Policies.

\section{Introduction}

Nowadays, the openness economic and accessibility to markets is the dominant feature of economic life and business in the local and international levels. Internationally, the success of openness and accessibility principles requires the lifting of restrictions, obstacles that hinder the freedom of trade exchanges, and limit products. ${ }^{1}$ However, these principles may have applied deliberately to harm others. Thus, the international trade law came to impose basic rules respected globally. ${ }^{2}$ The international trade law refers to rules and principles that are applicable to most of countries; these regulations either international customary law, multilateral treaties, agreements, and/or international trade law are indispensable and important, due to the following reasons:

i. It is the safe shield is behind that allow governments to protect its people interests, and a protection against trying to dump the markets and kill the economy.

ii. It is the protector and promotor of the social values and interests.

iii. It achieves the minimum level of equality in economic international relationships. ${ }^{3}$

\footnotetext{
"School of Business Management (SBM), College of Business (COB), Universiti Utara Malaysia, 06010 Sintok, Kedah, Malaysia. E-mail : kahlsne@gmail.com.

${ }^{1}$ Stiglitz (2003).

${ }^{2}$ Van den Bossche \& Zdouc (2008).

${ }^{3} \mathrm{Ibid}$
} 
Moreover, the international trade law and international agreements - or regional- about anti-dumping it was intentionally deliberated in more than one occasion. The main points were the need to raise the barriers of customers, and mainly fees imposed on goods entering to the local markets' agreements. For that, the General Conventions on Tariffs and Trade (GATT) prevents all signatory countries, who are seeking to join her to impose such operational measures on products entering to their markets, because this opposes to the basic principle of its provisions, and the free movement of goods and services.

\section{Background of the Study}

One of the main features of the international trades is the restrictions' lifting on goods and materials movements. Meanwhile, the international trade law imposes requirements to insure this movement and is considered as the famed and protector. Lifting restrictions on trade and supporting freedom of movement it may lead to another side of business practices which harms the economies. The foreign producers, dealers, and consumers might harm the local producers in many ways, an illegal business competition, an exploiting the lifting of customs, and an exploiting of the ease access to the local markets. These actions lead to sink commercial markets by products sold for less than the value of their production in order to dominate and control the market initially, control to pricing, and finally getting the large market share. ${ }^{4}$

In fact, this is what is called the market dumping, and for the protection from these acts and ethics the international trade agreements came to give freedom act and the right to all countries that affected by a commercial dumping to issuing a local law, and impose customs fees and restrictions on these import products, with the aim of secure their economics to face such practices. The World Trade Organization (WTO) consider as the protector of its members, this by return to agreement of Article VI on the General Agreement on Tariffs and Trade (GATT) in 1994, which was changed and became later the World Trade Organization (WTO) in $1995 .^{5}$

\section{Literature Overview}

According to Article VI on the GATT agreement, part one, article 2: 1-2

"For the purpose of this Agreement, a product is to be considered as being dumped i.e. Introduced into the commerce of another country at less than its normal value, if the export price of the product exported from one country to another is less than the comparable price, in the ordinary course of trade, for the like product when destined for consumption in the exporting country.",

\footnotetext{
${ }^{4}$ Jahlol (2011).

${ }^{5}$ Ibid

${ }^{6}$ Agreement on Implementation of Article VI- of General Agreement on Tariffs and Trade, 1994.
} 
Thus, in the simplest cases, one can identify dumping simply by comparing prices in two markets. On the other hand, the situation is rarely, if ever, that simple, and in most cases, it is essential to undertake a series of complex analytical steps in order to identify the suitable price in the market of the exporting country (known as the "normal value") and the suitable price in the market of the importing country (known as the "export price"), so as to be able to undertake an suitable comparison. ${ }^{7}$

For almost one hundred years, international trade policy makers have proceeded on the view that "dumping" is a practice that "is to be condemned" and have allowed the developing country to take certain countermeasures, at least when the dumped goods cause "material injury" to compete industries in the developing country. ${ }^{8}$

Anti-dumping law is well-known as a legal device that counteracts the practice of dumping by a foreign exporter. The counteract action appears to make perfect sense: If an exporter engages in unfair pricing in a foreign market with the goal of driving out incumbent producers, it must be counteracted by practicing the antidumping duty, this will neutralise the negative impacts. On the other hand, the consumers of an importing country at first may be considered beneficiaries of price discrimination, due to lower prices for imports, the main concern of governments which invoke anti-dumping measures against such imparts, is that in terms of the outcomes of international competition, the importing country might not reflect the underlying competitive positions of the domestic industry and its employees. This may lead to the domestic industry of the importing country being adversely affected. ${ }^{9}$

Furthermore, anti-dumping regulations are employed as a means of providing protection to the domestic industries and their workers from the injurious effects of unfair international price discrimination. The use of ant-dumping measures dates to the origins of the GATT and has been by far the most frequently used means of protecting domestic industries in the developed world from international competition. $^{10}$

Actual anti-dumping measures were the exception until the 1980s, although anti-dumping regulations were instituted in most countries before to the First World War. After having lowered the general import duties in the various GATT rounds, dumping measures became one of the most significant restrictions in global trade. Until the late 1980s, the most important users of antidumping laws were the USA, Australia, and Canada. Other developed countries such as Japan, Switzerland, Norway, Sweden, and Finland have anti-dumping laws on their books but have seldom invoked them. ${ }^{11}$

Since then a number of developing countries, beginning with Mexico have adopted anti-dumping laws and have begun using them; the history of antidumping actions dates back to at least one century ago, when Canada for the first

\footnotetext{
${ }^{7}$ Wto.org. (2016).

${ }^{8}$ Howell \& Ballantine (1997) at 271.

${ }^{9}$ Jahlol (2011).

${ }^{10}$ Ibid.

${ }^{11}$ Wto.org. (2016).
} 
time took such an action (1904); it has also demonstrated that in due course countries such as Australia, Great Britain and the USA. Also, they put in place anti-dumping legislation within the municipal framework. ${ }^{12}$

According to Zvidza (2008) the Uruguay Round brought about the biggest reform of the world's trading system since GATT was created at the end of the Second World War. It covered more issues and involved more countries than any previous round. Its Final Act prescribes, among other things, that tariffs on industrial products be reduced, and that a new body, the WTO, be established to facilitate the implementation of multilateral trade agreements and to serve as a forum for future negotiations.

The GATT contracting parties have had four opportunities to develop antidumping law:

1. In 1947 when the GATT was drafted;

2. Between 1964 and 1967 when the Kennedy Round Antidumping Code came into existence;

3. Between 1974 and 1979 when the Tokyo Antidumping Code was produced; and

4. Between 1986 and 1994 when the Uruguay Round Antidumping Code came into being. (Wto.org, 2016).

\section{Methodology}

Social research is a systematic study into social, political, or other factconditions, to discover unknown or party known factors working behind phenomenon, to understand why something happens and to draw inferences and general conclusions, it is to identify the cause and effect of certain problem. ${ }^{13}$ This paper is an attempt to find out the regulations and policies relating to AntiDumping in Algeria. In conduction this paper, it is intended to use the exploratory study on the Algerian law to know the legislation which related to the AntiDumping in Algeria. The armchair library approach employed for the collection of the primary legal materials. For this purpose, the Library of University Utara Malaysia, the Faculty of Law Library, and the Algerian High Court Library used to source the primary legal material. The secondary data, books, articles, reports, and online database equally sourced through the library approach.

\section{Results}

The Ethical Aspect of Anti-Dumping

Basically, the business activities based on trust, honesty and commitment of the required law rules. In the trade relations it must resort to the rules and

\footnotetext{
${ }^{12}$ Zvidza (2008)

${ }^{13}$ Yaqin (2007).
} 
principles of barely differ between the market and the other no matter how far or different details of dealing with them. In fact, the presence of controls for business behaviour of market deals is based mainly on ethical standards, the violation of these standards means breaking the proper handling rules. ${ }^{14}$

Regardless to religious principles, taking anything belong to others without their permission is unallowed. Most people have agreed that stealing is unethical act, this is simply meaning that you can not to take property does not belong to you. Moreover, there is a widespread consensus that destroying the property of others is a big mistake unless in case of self-defence, this is one hand. ${ }^{15}$

On the other hand, there is a basic ethical principle saying that, it is always unethical to initiate the use of force against others. That does not mean that selfdefence is unethical, or that pre-emptive strikes are unethical if the pre-emptive strike prevents someone from initiating force against you or violating your rights. ${ }^{16}$ These argument leads to impose the following questions: Does dumping is using of power with harm intention? is this led to violating of other rights or destroying their property? If the answer is yes, how the self-defence and pre-emptive strike will not depart from the ethical principles? Shortly, what are the unethical and ethical aspects of anti-dumping law?

Firstly, as mentioned above, dumping it is means that some company is selling its product for less than production cost or for less the domestic market than in some foreign market. The local producers might be harmed; they even close their own businesses by losing sales or found themselves forced to reduce products prices that cannot cover the production costs. However, this reduction of prices is never meaning that the market is under dumping, or their rights are violated by these foreign company or products that dump. Consequently, if any force implicated, it is the force of competition. This point view expresses the final customers' opinion; if the customers prefer to buy a foreign product and are cheaper than domestic counterpart and with best quality, they remain one of the customers' rights.

A sensible issue it should be discussed, how the final customer can safe his right to purchase quality products with low prices? the local producers/dealers cannot utilise the executively in local market or taking dumping action as a strong justification to violate people/customers' rights. Stealing is taking property that does not belong to you, all people agree with that, whether it was directly or with another way like rising products prices. Mostly, what happen exactly when the government initiates an anti-dumping act the business dealers utilise the law power to steal the people's money. The anti-dumping law become as an umbrella and cover where they raise the prices higher than the case in unhampered markets. For instance, if customers need to buy a car, they pay $15000 €$ instead of $8000 €$, so the anti-dumping law, which forces these people or customers to pay an extra of 7000 $€$ as a condition of doing business with foreign companies. This is a violation of consumers' rights and stealing of their money, this is in fact unethical side of antidumping.

\footnotetext{
${ }^{14}$ Jahlol (2011).

${ }^{15}$ McGee \& Block (1997).

${ }^{16}$ Ibid.
} 
Absolutely, the result does never change if consumers and customers decide to buy a domestic product because of the anti-dumping laws lead to higher prices of foreign product this leads to raise the price of domestic product too, because of reduce the competition. As a result, in the presence of anti-dumping law the property and contract rights of consumers are violated, whether they will buy a domestic or foreign product, the producer prices will be higher, because of the chilling effect on price competition. ${ }^{17}$

Secondly, which is assumptive, destroying other properties is unethical act. So, is anti-dumping law destroying the property of others? If the answer is yes, how is that? According to McGee and Block, (1997) the answer is a yes. The producers or the competitors find themselves in front of the obligation to pay heavy administrative and legal costs to defend its rights for selling, this costs it is almost similar thing like the destroying their properties. For example, forcing the competitors to spend $500,000 €$ of administrative cost and legal fees to defend itself in investigation of anti-dumping. So, it is not very different from a poke the fire in warehouse insides, but the only different is to give the first one a legal cover. The stealing and destroying the properties of others are not an ethical act, in any way or any reason.

Based on the above discussions, it can reasonably be deduced that anyone initiate anti-dumping action for any reason guilty of unethical behaviour. In fact, the anti-dumping law enacted to protect consumers from high prices. But these laws will be used unethically to reduce competition until market monopoly. Thus, it should prevent most of the local producers resorting to unethical anti-dumping laws to raise prices and steal part of the consumer's income.

On the other side, the ethical aspects of anti-dumping in the utilitarian ethics. Utilitarianism is an ethical philosophy espoused by all economics, so if we apply the utilitarian theory to know at what extent anti-dumping law are ethical?

Henry Sidgwick, an utilitarian and he extends this philosophy, as follows: 'an action is right if and only if it brings about at least as much net happiness as any other action that the agent could have performed; otherwise it is wrong do that". ${ }^{18}$ Basically, utilitarianism aims at the greatest good for the greatest number, but is the anti-dumping passes the utilitarian philosophy? No of course, because there is so many evidences against them. For example, in US, steel companies stand to benefits from the implication of anti-dumping law, which means the duties are imposed on foreign steel producers. These duties harm more than 20 producers in the world, let say all the industries in the US that must now pay higher prices for steel, and the consumers who purchase the product they will pay. For more explanation, if the he U.S. auto industry would have to pay more for steel, this would make it less competitive in international markets. Thus, auto manufactures would also suffer where dumping duties were imposed on foreign steel. So, it cannot achieve in this way of the general utilitarian, it is clearly that the antidumping laws fail in the utilitarian test because losers exceed winners. ${ }^{19}$

Anti-dumping Law as a Protector from the Negative Effects

\footnotetext{
${ }^{17}$ Ibid.

${ }^{18} \mathrm{McGee}(2000)$.

${ }^{19}$ Ibid.
} 
Companies could be aware of their responsibilities to the society, environment, customers, and suppliers, with aim to be good corporate citizen that is the last stage and the peak in Carlo's Corporate Social Responsibility (CSR) pyramid. The companies which dumping has not been in the first stage even, because its target is not only being profitable but also be harmful to the domestic and competitive companies.

The dumping has many effects, and mostly is negative and harmful for domestic producers, consumers, and the national economy. The following sentences highlight some effects:

- Higher losses to the local competitors represented in lower sales volume, loss of market shares, and the accumulation of stagnant inventory and the lower production and the using incomplete of resources and downturn their business.

- Higher losses to the domestic competitors, if they are trying to follow the seam methods.

- Downturn semi-industrial business and all related and associated activities that supported the main industries that lead to contraction all manufacturing businesses.

- An increase of unemployment rate after closing the business and losing the job opportunities

- Lake of public financial resources due to decrease of taxes on companies and enterprises that suffered losses or those that came out of the market.

- Squandering the available domestic resources, it is a main reason to trend toward monopoly, which leads to:

- Get away from the improvement of the level of production, and the elimination of the spirit of renewal, innovation's investment, production, and trade.

- The exclusion of any new investor wants to enter the market.

- Eliminate the safety of supply and demand rule that constitutes the essence of a market economy. ${ }^{20}$

\section{Anti-Dumping Actions}

The dumping action is prohibited by GATT / WTO, and the Member State which proves, that the goods dumped entered its markets, it has the rights to take a defensive action, represented by charging duty and costume fees of dumping or anti-dumping. When the goods are entering to the country in the customs border, and this is in accordance with Article VI of the GATT scholars ${ }^{21}$ stated that the value of these custom fees are usually equal to margin of dumping or does not exceed it. This margin which is defined as the difference between the price of the commodity in the domestic and overseas markets, and more specifically, the difference between the normal value and the export price.

\footnotetext{
${ }^{20}$ Gachi \& Benkamla (2013).

${ }^{21}$ Ibid.
} 
The adoption of the final anti-dumping procedure is practicing according to a specific and precise mechanism which was developed and organised by the World Trade Organization, which includes four stages and conditions as follow:

1. Open investigations after a complaint from the affected;

2. Must be an investigation to prove the existence of dumping;

3. Must be an investigation to prove the occurrence of physical damage to the domestic industry that produces a product compete for that dumped product;

4. Because of the harm and the presence of the dumping, this damage did not happen because of other factors. So, must be that there be a causal relationship between the dumping and the occurrence of damage. ${ }^{22}$

Typically, these final procedures apply during period of five years, before it finished it must doing a check/review by aim to know whether the damage or the existence of dumping may still both or one of them; in the event of vanishing, it is going to finishing the charging the customs fees immediately; In contrast, not to stop or cancel the last actions, and it remains until another review list; also, these parties concerned can require the review before the end of the five-year period. Usually, it is also to take preventive measures (temporary) before the final procedures and exactly during the period of investigation. At each step or stage, it shall be notified the anti-dumping procedures to World Organization Trade.

In addition to the U.S government which its companies and enterprises accuse the application of dumping, and companies that export goods concerning dumping, and domestic producer's owner's complaint. ${ }^{23}$ The state which applies the anti-dumping duties to its exports may see that such practices seek behind the protection of domestic producers; and primarily those who cannot compete. Therefore, it is a violation of WTO rules on anti-dumping, whereupon it can initiate a complaint against the government or state in front of the dispute Settlement system of WTO. ${ }^{24}$

\section{Anti-Dumping in Algeria}

Recently, it has been clear that Algeria have been taken stable steps to be more open on the world and keeping up with globalization. This openness made the Algerian national market wide open to all possibilities, whether is beneficial with serving the Algerian companies or cause harms to them. For that, to make this openness and the integration harmless to the local economy, the lawmaker enacts a set of legislation that regulates the trade and criminalises the dumping acts.

It should draw attention that Algeria refuses to join the World Trade Organization, and until 2007, it remains as a political decision taken by the

\footnotetext{
${ }^{22}$ Babili (2006).

${ }^{23}$ Gachi \& Benkamla (2013).

${ }^{24}$ Babili (2006).
} 
government. Simply, the position of Algeria as an observer in WTO is a comfortable position for government, as them says. ${ }^{25}$

All countries around the world, which pursue the protection of its economy institutions from dumping and its practices, keen to enact a set of laws. In fact, between 2005 and 2007 Algeria has been adopted the Trade Defense Measures MDC (Measures de Défense Commerciale -Fr-), that includes the terms and how to implement the compensation rights, anti-dumping measures, preventive measures, as well as the regulation of investigatory procedures in it. ${ }^{26}$ By the way, the Algerian anti-dumping legislation, and their contents does not totally differ from what is a prevalent in many countries.

\section{-Algerian national anti-dumping measures and their role in the accompaniment of companies}

As already mentioned, Algeria between the years 2005 and 2007 has enacted a set of legislation called the Trade Defense Measures MDC; this legislation was agreed in substance with anti-dumping legislation of many countries in this regard, but beyond that it was correspond with the legislation in Article VI of the GATT. According to 'Executive Decree No. 222-05 dated 15 May of 1426, corresponding to June 22, 2005, the conditions to implement the right anti-dumping and proceedings' (2005) by Algerian Houses of Business.

We can say that this legislation has not come only to protect the economic dealers or companies from unfair competition only but is a changing in the vision of Algerian government to be a member of World Trade Organization also. It states the following points:

1. The authority which has the right to open an investigation, and antidumping is the competent departments in the Ministry of Trade, and it does not apply anti-dumping duties only upon the achievement of the authority in charge of doing that. Also, the application of organization and investigation procedures is on as prescribed by the Minister of Trade.

2. The investigation will start based on a written request from the production branch of companies, or the presenter of their name, with present evidence of support degree or opposition from the other local producers of the request. This request for the investigation includes elements of justification shows sufficient facts and actual existence of dumping and damage. As well as the causal relationship between the importation products and the damage happen. This request also, should be includes all useful information relating to the complainant or its local production branch.

3. The period of examine the request and opening an investigation should be to not exceed forty-five days from the date of receive request, and during this period of studying it, must send form questions for the applicant, accused, and all parties concerned.

4. Give period of thirty days for foreign exporters and producers from the date of receiving the form questions to answer it, with ability to give am

\footnotetext{
${ }^{25}$ Quiedar \& Abdullah (2006).

${ }^{26}$ Gachi \& Benkamla (2013).
} 
extension if the exporters and producers demanded it with condition of providing a very convincing explanation.

5. The authority charged with the investigation provides during the investigation time, for all parties involved (the exporters and their governments, the local producers, and all the other parties local or foreign that can be considered relevant in view of the requirements of the investigation) the possibility of meeting, and possibility for each party to submit its justifications.

6. Immediately, the investigation will close in the case of whether of the authority in charge of investigation, determined that the margin of the dumping is very little, and/or the volume of the real or potential imports concerned by the dumping or damage is very limited. The dumping margin is very little if it is less than $2 \%$ for the export price, and the volume of imports concerning the dumping that is little, if it represents less than $3 \%$ of the volume of imports of the same product in the local markets.

7. The investigation closing will be in a maximum period eighteen month, unless there are special circumstances.

8. Normal value and dumping margin do not calculated unless the investigation authority identified, that the sales of imports concerned of dumping has been in a period ranging between six (6) and twelve (12) months, and in quantities greater than twenty percent (20\%) of the total volume of transactions, which was considered for identifying or determining the normal value.

9. When determining the damage, is should be considered whether the volume of imports concerned of dumping is show in total a huge increase. Moreover, these imports were had a reflection on the national producers may be impacted on the situations of this sector.

10.The anti-dumping tax fees will be in the form of a cash guaranty deposit or bank guaranty and being equal to the dumping amount which is calculated temporary. This fee does not apply if there is no positive determining existence of dumping and damage, and that action is necessary to prevent any damage may occurs during the period of investigation. Only after 60 days from the date of starting the investigation until a period not exceeding four 4 months.

11.Suspend or close the investigation without the application of anti-dumping duties, temporary or definitively, will be if the agent vowed to revise its prices or not exporting in the future with dumping prices. ${ }^{27}$

\section{Cases from Algeria}

The Algerian government in the begun of February 2013 imposed new tax to reduce the importation of rebar and other steel products from the 17 countries which are part of the Great Arab Free Trade Agreement (GAFTA).

The authorities published a list of goods (including rebar) and it has been applicable from February 1st, 2014, the main act have been taken is that exclude

${ }^{27}$ Executive Decree No. 222-05. 
all GAFTA members from the benefiting of import duty exemptions. As a result, rebar imports from the GAFTA countries are now subject to a $15 \%$ import tax that make the business of these types of raw materials bootlicker even for nearby countries such as Morocco (one of the largest rebar producers) to trade with Algeria. These procedures were taken because of the dumping of internal market by rebar that what influenced to domestic producers, and the main producer 'Sonasid' (government-owned), which leads to economic damage.

Another example happened in the period from 2003 until 2011 between Algeria and European Union, when the European Union imposed an anti-dumping tax on the Algerian fertilizers and pesticides, in order to protect their companies and then its economy, Algeria tried to explain this case and this problem to EU, but the bid by Algerian company 'Urea Ammonium Nitrate' (UAN) the producer of fertilizer has be exempted from tax of $13 \%$, anti-dumping duties imposed on exports to the European Union has failed. This $13 \%$ tax hit that far Algerian exports of fertilizer, had been established by the EU, following a complaint from the European association of producers of fertilizers, which had held that the fertilizer products in some countries came gas cheaper in the European market.28

However, Algeria has challenged this unilateral action, going against the free trade, by initiating discussions in 2007 to its cancellation. It had been provided for this purpose in the European part of the explanation of the composition of gas prices, which had shown that while the price of this energy well practiced in Algeria covers the costs of exploration, extraction, transportation, storage but also implies an adequate profit margin for reinvestment; and also, our government explained that: 'there is no support from the state's gas prices, no hidden subsidy from the state to fertilizers companies'.

For this the EU lifted officially the anti-dumping tax imposed on Algerian exports of fertilizers; and 'the notice of expiration of this anti-dumping measure, which took effect from 22 December 2011 was finally released late last December in the official journal of the EU'.29

\section{Conclusion}

In addition to the legal and economic sense for the business dumping represented as entry of certain products to the other countries at a price less than the total value of production, it can be argued that, the other important findings spin in this context; is an ethical and an unlawful act. The commercial dumping in reality is unfair competition, due to the exiting duties in business dealing in general, which results in a range of legal and economic impacts. Generally, the dumping leads to the economic shrinkage, and inhibiting the economic development efforts; with disorder of dealing, and lack of respect, for the rules of fair competition; also, the imposition of antidumping duties that leads directly to

\footnotetext{
${ }^{28}$ Antidumping.vn (2012).

${ }^{29}$ Icis.com (2014).
} 
an increase in commodity prices to consumers. The Algerian government condemns the dumping acts and is made huge efforts to combat it.

\section{References}

Agreement on Implementation of Article VI of The General Agreement on Tariffs and Trade 1994. Available at: http://www.wto.org/english/docs_e/legal_e/19-adp.pdf

Jahlol, A.H. (2011). The Commercial Dumping. Alqadisia Journal, ISSN: 01371097 Year: 2011 Issue: 2 Pages: 87-129, (in Arabic: عمار حبيب جهلول ، مجلة القادية للقانون و العلوم السياسية), Available at: https://www.iasj.net/iasj?func=article\&aId=12959 (accessed 12 December 2017)

Antidumping.vn (2012). EU lifts officially the anti-dumping tax imposed on Algerian exports of fertilizers | Information on anti-dumping, anti-subsidy and safeguard measures. Retrieved 1 November 2017, from http://antidumping.vn/eu-lifts-official ly-the-antidumping-tax-imposed-on-algerian-exports-of-fertilizers-n10624.html

Executive Decree No. 222-05 dated 15 May In 1426, corresponding to June 22 2005, the conditions to implement the right anti-dumping and proceedings. (2005) Available at: http://www.mincommerce.gov.dz/arab/fichiers/dec05222ar.pdf (accessed 25 November 2017)

Gachi, F. \& M.A. Benkamla (2013). "The role of the anti-dumping legislation in the accompanying activity of small and medium-sized enterprises in Algeria", Available

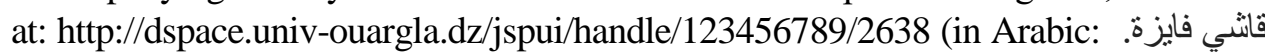
بن كُاملة محمد عبد العزيز. دور تشريعات مكافحة الإغراق في مرافقة نشاط المؤسسات الصغيرة و المتوسطة في الجزائر. accessed 12 November 2017)

Howell, T. R., \& D. Ballantine (1997). Dumping: still a problem in international trade. International Friction and Cooperation in High-Technology Development and Trade: Papers and Proceedings, 271.

Icis.com (2014). Algeria's Fertial fails to lift EU anti-dumping duty on UAN. Available at: http://www.icis.com/resources/news/2005/06/28/688832/algeria-s-fertial-fails-to-lifteu-anti-dumping-duty-on-uan/ (accessed 1 November 2017)

Babili, M. (2006). Anti-dumping: Attitudes- negotiations and their importance for Syria, Policy Note No. 17. Available at: from http://www.napcsyr.net/dwnld-files/divisions /tpd/pubs/pol_brf/ar/17_pol_brf_antidumping_mb_ar.pdf (accessed 25 October 2017)

McGee, R. (2000). 'Some Ethical Aspects of Antidumping Laws. Reason Papers'. Vol. 25:55-67. http://ssrn.com/abstract $=442660$.

McGee, R. \& W. Block (1997). 'Ethical aspects of initiating anti-dumping actions', in International Journal of Social Economics, 24(6): 599-608.

Quiedar A. \& I. Abdullah (2005).'The effects of Algeria's accession to the World Trade Organization between optimism and pessimism. Journal of North Africa Economies.

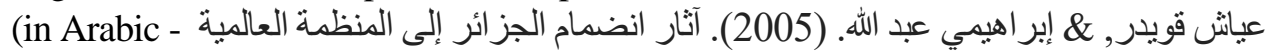

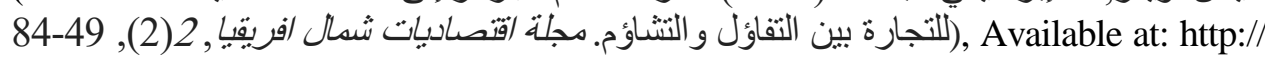
www.univ-chlef.dz/RENAF/Articles_Renaf_N_02/article_02.pdf (accessed 15 November 2017)

Stiglitz, J. (2003). 'Globalization and the economic role of the state in the new millennium' in Industrial and Corporate Change, 12(1): 3-26.

Van den Bossche, P. \& W. Zodouc (2008). The Law and Policy of the World Trade Organizations. Cambridge University Press. 
Wto.org. (2014). WTO | Understanding the WTO - The Uruguay Round. Available at: http://www.wto.org/english/thewto_e/whatis_e/tif_e/fact5_e.htm (accessed 12 September 2017)

Wto.org (2016). WTO | Anti-dumping - Technical Information. (online) Available at: https://www.wto.org/english/tratop_e/adp_e/adp_info_e.htm (Accessed 4 Feb. 2018).

Yaqin, A. (2007). Legal research and writing. Kelana Jaya, Selangor: Mal ayan Law Journal. 
